\title{
PENERAPAN KESELAMATAN PASIEN OLEH PERAWAT DI RUMAH SAKIT JIWA
}

\author{
SRI HARVITA SARI MARPAUNG / 181101125 \\ $\underline{\text { Sriharvitaaasm11@gmail.com }}$
}

\begin{abstract}
ABSTRAK
Latar belakang : penerapan keselamatan pasien oleh perawat di rumah sakit jiwa

Tujuan : untuk memberikan informasi mengenai penerapan program keselamatan pasien di lingkup rumah sakit jiwa

Metode : menggunakan literature riview berdasarkan teks book, jurnal, e-book (10 tahun terakhir) dengan cara menganalisis, eksplorasi sumber dan kajian bebas.

Hasil : pengaplikasian penerapan keselamatan pasien di rumah sakit jiwa

Pembahasan : keperawatan jiwa, patient safety di rumah sakit jiwa, pengawasan patient safety di rumah sakit jiwa

Kesimpulan : dengan penerapan program keselamatan pasien di rumah sakit dapat mengurangi angka kecelakaan/cedera pada pasien di rumah sakit jiwa guna meningkatkan pelayanan kesehatan yang berkualitas.
\end{abstract}

Kata kunci : perawat, rumah sakit jiwa, keselamatan pasien.

\section{LATAR BELAKANG}

Rumah Sakit Jiwa pada dasarnya dihuni oleh pasien yang sakit "mental", baik ringan, sedang, maupun berat. Dengan sendirinya karakteristik pasien maupun tata ruang dalam bangsal RSJ agak berbeda dengan rumah sakit pada umumnya. Pasien penghuni RSJ nantinya akan mengikuti program rehabilitasi. Program ini membutuhkan waktu yang cukup lama karena merupakan rangkaian kegiatan yang melibatkan banyak hal mulai dari yang bersifat medik, sosial, pendidikan ataupun vokasional (DepKes RI 1985). Sehingga masa sebelum mengikuti program rehabilitasi ini pasien diwadahi dibangsal atau unit rawat inap. Intensitas penggunaan bangsal yang tinggi oleh pasien mental membutuhkan perhatian yang lebih besar terhadap tata ruang dalam bangsal tersebut.

Pasien RSJ memiliki karakteristik yang berbeda dari pasien rumah sakit pada umumnya. Pasien RSJ adalah pasien yang terganggu kesehatan mentalnya. Kesehatan mental menurut faham ilmu kedokteran (DepKes RI,1985) ialah suatu kondisi yang memungkinkan perkembangan fisik, intelektual, dan 
emosional yang optimal dari seseorang dan perkembangan itu berjalan selaras dengan keadaan orang lain. Konflik atau permasalahan mental (mental disorder) yang biasanya terjadi dapat disebabkan antara lain (Kartono, 1980: 21) oleh: terbentur pada standar dan norma sosial tertentu, konflik kebudayaan, masa transisi di Indonesia, tingkat aspirasi terhadap kemewahan material. Konflikkonflik ini dapat menyebabkan terganggunya fungsi kejiwaan seseorang. Termasuk semua jenis gangguan jiwa pada prinsipnya memerlukan usaha rehabilitasi, terutama di dalamnya pasien golongan kronik yang perjalanan penyakitnya tak jelas dan menimbulkan disabilitas psikososial. Pentingnya pemeliharaan kesehatan jiwa ini juga dapat dilihat dari kecenderungan jumlah pasien yang terus meningkat lima tahun terakhir di RSJ Prof. dr. Soeroyo tersebut. Pada tahun 1997 jumlah pasien yang masuk perawatan 1.430 orang, sedangkan tahun 2001 menjadi 2.075 orang (RSJ Prof. dr. Soeroyo, 2002). Selain itu pemeliharaan kesehatan mental memiliki hubungan yang erat dengan pemeliharaan kesehatan fisik. Keduanya saling menunjang terhadap perkembangan tingkat kesehatan seseorang. Kesehatan fisik yang terjaga baik akan menumbuhkan pola hidup sehat yang berdampak secara psikis dalam kepribadian seseorang. Walaupun tidak selalu benar, penderita gangguan mental kadang - kadang menunjukkan keadaan jasmani yang memuaskan. Sedangkan cacat fisik tidak selalu menjamin adanya cacat mental (Meichati, 1983:18).

Pasien mental pada RSJ dengan berbagai kondisi mulai dari gangguan schizophrenia, psikosi, psikoneurosis, psikosomatik dan lainlain memiliki berbagai macam karakter kejiwaan. Karakter kejiwaan tersebut secara garis besar terbagi menjadi dua macam golongan yaitu golongan gaduh gelisah (ditangani secara intensive care) dan golongan tenang (ditangani secara intermediate care).

Bagaimana sudah kita ketahui bahwa dalam pemberian layanan kesehatan harus bekualitas dan dapat meningkatkan derajat kesehatan pasien, maka dalam kasus ini penerapan keselamatan pasien tetap di terapkan sekalipun lingkupnya adalah RSJ.

\section{TUJUAN}

Tujuan dari penulisan ini adalah untuk memberikan informasi mengenai 
penerapan program keselamatan pasien

di lingkup rumah sakit jiwa.

\section{METODE}

Metode yang digunakan dalam penulisan ini menggunakan literature riview berdasarkan teks book, jurnal, $e$ book (10 tahun terakhir) dengan cara menganalisis, eksplorasi sumber dan kajian bebas.

\section{HASIL}

Hasil yang diharapkan dari penulisan ini adalah dapat mengaplikasikan program keselamatan pasien di rumah sakit jiwa yang bertujuan meningkatkan derajat kesehatan pasien dan meningkatkan pelayanan kesehatan yang berkualitas.

\section{PEMBAHASAN}

\section{A. Pengertian Keperawatan Jiwa}

Menurut American Nurses Associations (ANA), Keperawatan jiwa adalah area khusus dalam praktek keperawatan yang menggunakan ilmu tingkah laku manusia sebagai dasar dan menggunakan diri sendiri secara teraupetik dalam meningkatkan, mempertahankan, memulihkan kesehatan mental klien dan kesehatan mental masyarakat dimana klien berada (American Nurses Associations).

Keperawatan jiwa adalah pelayanan keperawatan profesional didasarkan pada ilmu perilaku, ilmu keperawatan jiwa pada manusia sepanjang siklus kehidupan dengan respons psiko-sosial yang maladaptif yang disebabkan oleh gangguan bio-psiko-sosial, dengan menggunakan diri sendiri dan terapi keperawatan jiwa (komunikasi terapeutik dan terapi modalitas keperawatan kesehatan jiwa) melalui pendekatan proses keperawatan untuk meningkatkan, mencegah, mempertahankan dan memulihkan masalah kesehatan jiwa klien (individu, keluarga, kelompok komunitas)

\section{B. Patient Safety dalam} Keperawatan Jiwa

\section{Delapan Insiden Pasien Safety} di Keperawatan Jiwa

Dalam keperawatan jiwa ada delapan inseden keselamatan pasien yang sangat sering terjadi yaitu :

- Violence and Aggression

Violence dan Agresssion ini merupakan bentuk insiden yang terjadi akibat adanya kekerasan dan penyerangan.

- Patient Victimization.

Adanya kebohongan ataupun menjadikan pasien sebagai korban

- $\quad$ Suicide and Self-Harm. Insiden berupa pasien yang bunuh diri dan membahayakan dirinya sendiri

- Seclusion and Restraint. Insiden berupa pengasingan dan pengekangan bagi pasien jiwa

- Falls and Other Patient Accidents. 
Kejadian berupa kecelakaaan atau jatuhnya pasien

- Absconding and Missing Patients.

Adanya pasien yang lari dari rumah sakit jiwa

- Adverse Medication Events. Insiden berupa pengobatan yang tidak cocok dan merugikan pasien

- Adverse Diagnostic Events. Terjadi adanya kesalahan diagnostik

\section{Patient Safety pada Pasien}

\section{Jiwa}

Perawatan pasien jiwa dengan

menerapkan pasien safety bisa

dilakukan dengan menerapkan hal-hal berikut ini :

$\checkmark$ Melindungi pasien dari membahayakan dirinya sendiri

Dilakukan dengan memantau pasien dengan kecenderungan untuk bunuh diri atau menyebabkan kerugian bagi diri mereka sendiri dan menempatkan mereka tetap di bawah pengawasan, menngeksplor isi pikiran mereka, mencoba untuk mengalihkan perhatian mereka dari ide-ide bunuh diri tersebut, mencoba untuk mengisi waktu mereka dengan kegiatan yang berbeda dan memberi mereka harapan dalam hidup , menempatkan mereka dalam lingkungan yang aman di bangsal jauh dari stimulator eksternal untuk ide-ide bunuh diri dan jauhkan dari benda berbahaya yang ia bisa gunakan untuk untuk membahayakan dirinya sendiri.

$\checkmark$ Melindungi pasien dari kasus prognosis

$\checkmark$ Melindungi pasien dari bahaya yang dilakukan oleh orang lain

Dilakukan dengan memonitor perilaku agresif dan memprovokasi fisik (perkelahian) agar tidak terjadi di antara pasien, delusi dan keyakinan yang salah juga dipantau untuk mencegah pasien dari menyebabkan kerugian bagi satu sama lain karena delusi atau keyakinan dan dalam hal apapun kontak fisik antara pasien perawat secepat mungkin dengan menggunakan intervensi benar, juga pasien dari kelompok usia yang relatif kecil dan jenis kelamin harus dipisahkan untuk mencegah kekerasan seksual (laki-laki - perempuan) (dewasa - remaja - anak-anak).

$\begin{array}{rlrr}\checkmark & \text { Melindungi pasien } & \text { dari } \\ & \text { kesalahan medis atau } \\ & \text { keperawatan. } & \\ \checkmark & \text { Melindungi pasien dari } \\ & \text { lingkungan fisik }\end{array}$


Dilakukan dengan memastikan bahwa pasien ditempatkan dalam tempat aman dan bebas dari benda-benda berbahaya yang mungkin melukai pasien atau digunakan untuk menyebabkan kerusakan baginya misalnya (Hanya peralatan makanan plastik dapat digunakan di lingkungan, tidak ada benda tajam yang diperbolehkan di lingkungan)

Tingkat kesadaran pasien harus dipantau untuk mencegah kemungkinan bahaya jatuh, untuk pasien yang terancam jatuh selama tindakan pencegahan tidur seperti sidereal, menempatkan pasien di tempat tidur klausul ke pintu, penurunan ketinggian tidur harus dilakukan.

\section{Patient Safety Selama Masa} Penahanan dan Pengasingan

Hal-hal yang dilakukan dalam menjalankan patient safety untuk pasien jiwa selama masa penahanan antara lain :

a. Jangan pernah lakukan penahanan diluar perintah medis.

b. Jangan pernah menggunakan penahanan sebagai metode hukuman atau untuk membalas dendam pribadi. c. Selalu memberitahu pasien alasan penahanannya

d. Pastikan bahwa penahanan tidak memblokir sirkulasi darah.

e. Periksa pasien dan ambil tandatanda vital setiap 15 menit.

f. Pastikan suhu ruangan sesuai

g. Selalu lakukan penahanan pasien dalam posisi terlentang.

h. Pastikan bahwa kebutuhan fisik pasien terpenuhi.

i. Penahanan tidak berlaku pada kasus operasi mata , operasi tulang belakang, kondisi hati, dada dan masalah pernapasan.

j. Ruangan fisik sekitarnya harus sesuai dan dilengkapi

k. Penahanan perlu adanya kamera pemantau

1. Pasien harus dimonitor pada semua waktu penahanan

Hal-hal yang dilakukan dalam menjalankan patient safety untuk pasien jiwa selama masa pengasingan antara lain :

a. Jangan pernah menggunakan pengasingan diluar perintah medis.

b. Jangan pernah menggunakan pengasingan sebagai hukuman atau balas dendam pribadi. 
c. Selalu memberitahu pasien alasan menempatkan dia dalam pengasingan.

d. Memeriksa pasien setiap 15 menit.

e. Pastikan bahwa ruang bebas dari bahaya.

f. Pastikan bahwa fisik ruang sekitarnya tepat dan dilengkapi dengan kamera pemantau.

g. Pastikan bahwa kebutuhan fisik pasien terpenuhi.

h. pengasingan tidak harus dilakukan pada kasus-kasus risiko bahaya diri, autis, jantung dan gangguan pernapasan dan pasien fobia

\section{Patient Safety dalam} Keperawatan Jiwa dikaitkan dengan 6 SKP

a. Identifikasi pasien : dalam pengindentifikasian pasien jiwa, hal ini harus diperhatikan perawat. Dalam pengidentifikasian ini, ditekankan kepada keluarga pasien pada saat pasien masuk ke rumah sakit.

b. Komunikasi : sasaran pasien safety komunikasi ini sangat diperlukan bagi perawat. Karena komunikasi adalah salah satu terapi yang efektif dalam menghadapi pasien gangguan jiwa.

c. Tepat obat: dalam menghadapi pasien jiwa, pasien harus memperhatikan keselamatan pasien pada obat-obatan, karena obat yang digunakan pada pasien dengan gangguan jiwa merupaka obat NAPZA. Jadi perawat harus memperhatikan penggunaan obat, nama obat, dosis agar tidak menimbulkan gangguan lain pada pasien

d. Tepat pasien, tepat lokasi, tepat sasaran operasi : sasaran ini tidak terlalu spesifik di dalam keperawatan jiwa.

e. Penurunan resiko infeksi : infeksi nosokomial merupakan masalah yang umum yang terjadi pada pasien yang dirawat di rumah sakit. Pada pasien gangguan jiwa, hal ini juga harus diperhatikan. Contohnya, pada saat pemberian injeksi, perawat harus memperhatikan penggunaan jarum suntik sekali pakai.

f. Resiko jatuh : pada sasaran ini setiap pasien yang mengalami 
resiko jatuh akan diberi tanda

kuning.

C. Standar Pengelolaan Pasien Safety dalam Keperawatan

Jiwa

I. Standar 1: Falsafah dan Tujuan

Kegiatan pengendalian infeksi di

Rumah Sakit Jiwa merupakan suatu keharusan untuk melindungi pasien dari kejangkitan infeksi, dalam bentuk upaya pencegahan, surveilens. dan pengobatan yang rasional.

II. Standar 2: Administrasi dan Pengelolaan

Harus ada panitia yang bertanggung jawab. mengatur, dan meninjau pengendalian infeksi.

III. Standar 3 : Staf dan Pimpinan

Pimpinan dan staf diberikan

kewenangan dalam pengelolaan

program pengendalian infeksi.

IV. Standar 4 : Fasilitas dan

Peralatan

Perlengkapan untuk kebersihan Rumah

Sakit Jiwa harus disediakan, demikian pula lingkungan harus bersih.

V. Standar 5. Kebijakan dan

Prosedur

Kriteria:

- Petugas Kebersihan
Harus ada jadwal kerja minimal 3 kali untuk membersihkan lantai atau setiap kali ada pengotoran lantai.

- Linen

Kereta untuk membawa linen kotor harus dicuci dan didesinfeksi secara leratur setiap hari. Linen bekas pasien infeksi harus dipisahkan dan didesinfeksi khusus. Ruangan serta tempat kerja laundri dibersihkan setiap hari. Staf harus mencuci tangan secara teratur dengan anti septik. Dilarang merokok di ruang linen. Bila linen disiapkan di luar Rumah Sakit Jiwa. harus dipastikan bahwa proses dapat dipertanggung jawabkan.

- Pengudaraan dan ventilasi

Harus dibuktikan bahwa mesin pendingin udara diperiksa secara teratur dan terbukti bersih dari jamur dan bakteri. Dilarang merokok di Rumah Sakit Jiwa.

- Pembuangan sampah

Sampah harus dibuang sedemikian rupa agar sesuai dengan peraturan yang ada. Harus ada batasan dan prosedur mengenai:

- Sampah yang terkontaminasi

Pemisahan sampah umum dan sampah medis yang terkontaminasi 
- Penanganan yang tepat dengan kantong, baju pelindung. dan tempat sampah sebelum sampah dimusnahkan.

- Harus ada tempat khusus bagi alat bekas suntik dan dibuang dengan cara yang aman agar tidak mecelakakan orang lain,

- Sumber air

$\checkmark$ Kualitas air harus baik, bila mungkin berasal dan PAM, bila berasal dari sumber lain harus dibuktikan bahwa secara mikrobiologik dapat dipertanggung jawabkan.

$\checkmark$ Bila terdapat penampungan air maka secara berkala "harus ada pemeriksaan mengenai kebersihan dan mikrobiologi.

VI. Standar 6 : Pengembangan Staf dan Pendidikan Semua staf berhak mendapatkan kesempatan pengembangan kemampuan dan keterampilan melalui program pendidikan.

VII. Standar 7 : Evaluasi dan Pengendalian Mutu Harus ada prosedur untuk menilai mutu pelayanan dan ada mekanisme untuk mengatasi masalah.

\section{KESIMPULAN}

Dengan penerapan program

keselamatan pasien di rumah sakit dapat mengurangi angka kecelakaan/cedera pada pasien di rumah sakit jiwa guna meningkatkan pelayanan kesehatan yang berkualitas.

\section{REFERENSI}

Ainin. H. (2015). Faktor - Faktor yang Berhubungan dengan Pelaksanaan Pencegahan Resiko Jatuh yang Dilakukan Oleh Perawat di RS. Jurnal Keperawatan. STIKes Husada Surakarta. 
Cahyono, J. B. S. (2012). Membangun

Budaya Keselamatan Pasien dalam

Praktek Kedokteran. Yogyakarta

Deswani. (2009). Proses Keperawatan dan Berpikir Kritis. Jakarta : Salemba Medika

Departemen Kesehatan RI. (2006).

Panduan Nasional Keselamatan Pasien Rumah sakit. Jakarta : Depkes RI

Gede, M. A. A. (2011). Manajemen Mutu Pelayanan Kesehatan. Jakarta : EGC

Harus, B. D. (2015). Pengetahuan Perawat tentang Keselamatan Pasien dengan Pelaksanaan Prosedur Keselamatan Pasien Rumah Sakit (KPRS) di Rumah Sakit Panti Waluya Sawahan Malang. (Jurnal CARE), Vol. 3, No. 1, Tahun 2015.

Kemenkes RI. (2013). Panduan Keselamatan Pasien. Jakarta

Marquis, B.L. (2010). Kepemimpinan dan Manajemen Keperawatan: Teori dan Aplikasi. Jakarta : EGC

Nursalam. (2011). Manajemen Keperawatan: Aplikasi dalam Keperawatan Profesional, ed.3. Jakarta : Salemba Medika.

Oktaviani. S. (2012). Pengetahuan dan Sikap Keluarga tentang Pencegahan Kejadian Jatuh pada Lansia di Kelurahan Pahlawan Binjai. E journal. Vol. 1. No. 3. Tahun 2012
Oktaviani. H. Dkk. (2015). Hubungan Pengetahuan dengan Kepatuhan Perawat dalam Pelaksanaan Standar Operasional Pencegahan Resiko Jatuh Pasien di RS Panti Waluya Surakarta. Jurnal Keperawatan. STIKes Kusuma Husada Surakarta

Perry \& Potter. (2005). Fundamental Keperawatan : Konsep Proses dan Praktek. Jakarta : EGC

Rivai F, Sidin A.I, Kartika I. (2016). Faktor yang Berhubungan dengan Implementasin Keslamatan Pasien di RSUD Ajjappannge Soppeng Tahun 2015. Volume 05

Simamora, R.H. (2018). Buku Ajar Keselamatan Pasien Melalui Timbang Terima Pasien Berbasis Komunikasi Efektif: SBAR

Stanley, M. (2006). Buku Ajar Keperawatan Gerontik. Edisi 2. Jakarta: EGC 